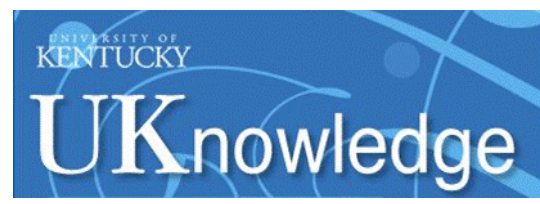

University of Kentucky

UKnowledge

Educational, School, and Counseling

Psychology Faculty Publications

Educational, School, and Counseling

Psychology

$5-1-2006$

\title{
Making High School Grades Meaningful
}

\author{
Thomas R. Guskey \\ University of Kentucky, GUSKEY@UKY.EDU
}

Follow this and additional works at: https://uknowledge.uky.edu/edp_facpub

Part of the Educational Assessment, Evaluation, and Research Commons, and the Secondary

Education Commons

Right click to open a feedback form in a new tab to let us know how this document benefits you.

\section{Repository Citation}

Guskey, Thomas R., "Making High School Grades Meaningful" (2006). Educational, School, and Counseling Psychology Faculty Publications. 30.

https://uknowledge.uky.edu/edp_facpub/30

This Article is brought to you for free and open access by the Educational, School, and Counseling Psychology at UKnowledge. It has been accepted for inclusion in Educational, School, and Counseling Psychology Faculty Publications by an authorized administrator of UKnowledge. For more information, please contact UKnowledge@lsv.uky.edu. 


\section{Making High School Grades Meaningful}

Digital Object Identifier (DOI)

https://doi.org/10.1177/003172170608700910

\section{Notes/Citation Information}

Published in Phi Delta Kappan, v. 87, issue 9, p. 670-675.

(C2006, Thomas R. Guskey

The copyright holder has granted the permission for posting the article here. 


\section{Making High School Grades Meaningful}

Most teachers base students' grades on more than one factor.

The difficulty is figuring out how to weight and combine the different pieces that go into the final mark. Mr. Guskey suggests a system that not only avoids those problems but gives a better overall picture of a student's performance than the traditional single letter grade.

BY THOMAS R. GUSKEY

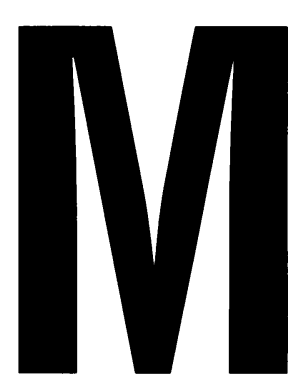

ICHAEL AND Sheila attend the same high school and take many of the same classes. Michael is an exceptionally bright but obstinate student. He consistently gets high grades on classroom quizzes and tests, even though he rarely completes homework assignments and is often tardy. His compositions and reports show keen insight and present thoughtful analyses of critical issues but are usually turned in two or three days late. Because of his missing homework assignments and lack of punctuality, Michael receives C's in most of his classes, and his grade-point average lands him in the middle of his high school class rankings. But Michael scores at the highest level on the state

$\overline{T H O M A S ~ R . ~ G U S K E Y ~ i s ~ a ~ p r o f e s s o r ~ i n ~ t h e ~}$ College of Education, University of Kentucky, Lexington. O2006, Thomas R. Guskey.

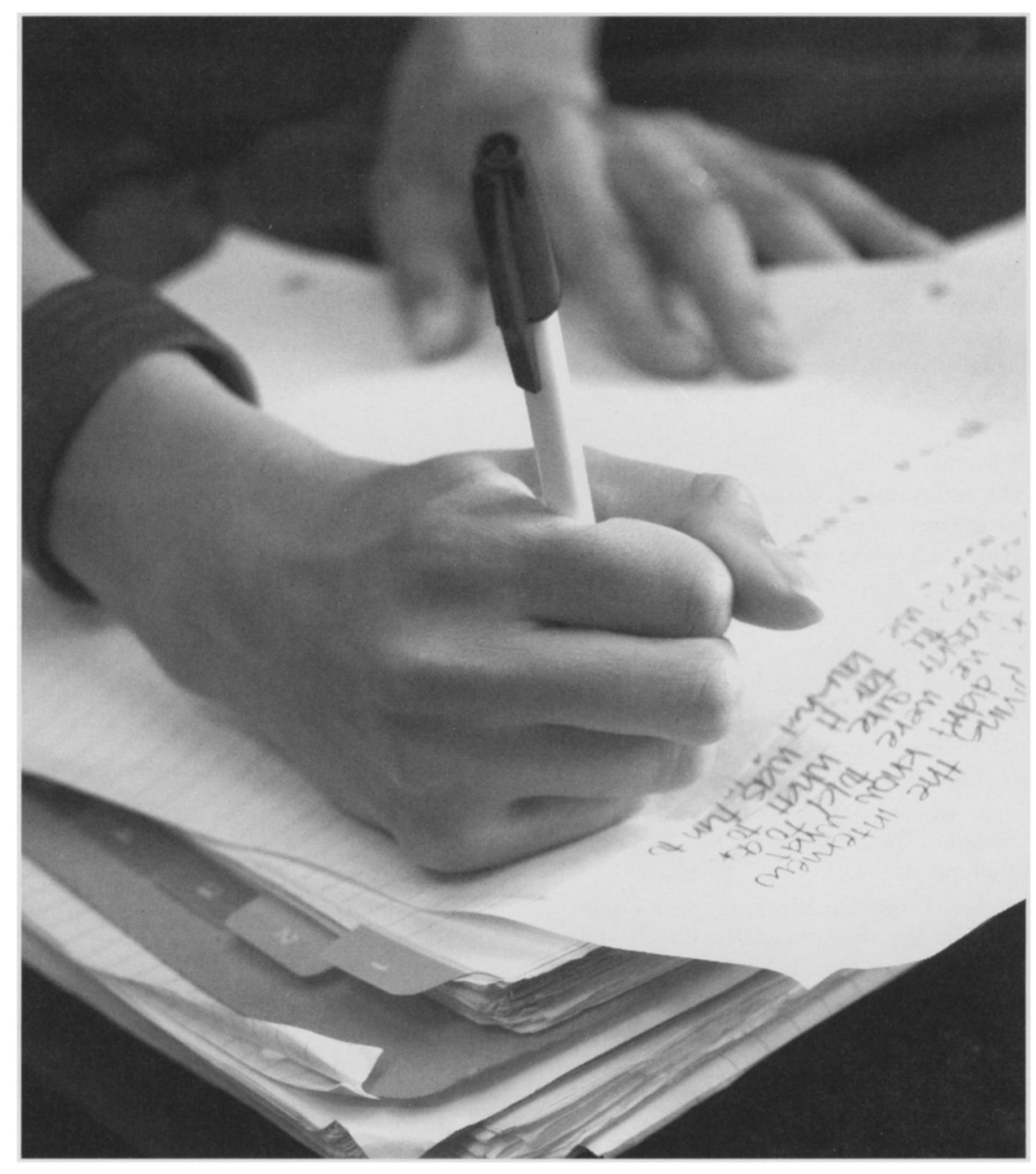

Photo: PhotoSpin 
accountability assessment and qualifies for an honors diploma.

Sheila, on the other hand, is an extremely dedicated and hard-working student. She completes every homework assignment, takes advantage of extra-credit options in all of her classes, and regularly attends special study sessions held by her teachers. Yet, despite her efforts, Sheila often performs poorly on classroom quizzes and tests. Her compositions and reports are well organized and turned in on time but rarely demonstrate more than a surface understanding of critical issues. Sheila also receives C's in most of her classes and has a class ranking very similar to Michael's. But because she scores at a low level on the state accountability assessment, Sheila is at risk of receiving an alternative diploma.

A rare situation, you say? Unlikely or even impossible? Ask any high school teacher today and most will tell you that they know students very much like Michael and Sheila. Many will admit that they currently have similar students in their classes. While Michael and Sheila may not be typical high school students, they also are not unusual.

How is it possible for students with such different levels of demonstrated knowledge and skill to receive essentially the same grades in their high school classes? How can they have roughly the same grade-point average and class ranking? What does this tell us about the meaning of high school grades and the students who receive those grades? And, most important, what does this tell us about the grading policies and practices of many high school teachers?

\section{HODGEPODGE GRADING}

Many educators contend that the problem lies in the accountability assessments. They believe that the discrepancy between high school course grades and scores on state accountability assessments demonstrates the inadequacy and invalidity of the assessment results. ${ }^{1}$ Indeed, these narrow once-a-year assessments may not reveal the true scope or depth of students' knowledge and skills. On the other hand, policy makers argue that teachers are the source of the problem. They think the mismatch between grades and scores on accountability assessments stems from bias and subjectivity in teachers' grading practices. ${ }^{2}$ There is ample evidence that most teachers receive little training in effective grading and that unintentional bias often influences teachers' grade assignments. ${ }^{3}$ However, a more likely explanation lies in the nature of grading itself and in the challenges teachers face in assigning grades that offer a fair and accurate picture of students' achievement and performance.

High school teachers today draw from many different sources of evidence in determining students' grades, and studies show that teachers differ in the procedures they use to combine or summarize that evidence. ${ }^{4}$ Some of the major sources of evidence teachers use include:
- Major exams or compositions

- Reports or projects

- Student portfolios

- Exhibits of student work

- Laboratory projects

- Student notebooks or journals

- Classroom observations

- Oral presentations
- Class quizzes
- Homework completion

- Homework quality

- Class participation

- Work habits and neatness

- Effort

- Attendance

- Punctuality of assignment submissions

- Class behavior or attitude

- Progress made
When asked which of these sources of evidence they consider in determining students' grades, some portion of teachers will report using each one of the elements on the list. When asked how many of these sources of evidence they include, however, responses vary widely. Some teachers base grades on as few as two or three elements, while others incorporate evidence from as many as 15 or 16 - and this is true even among teachers who teach in the same school.

Two factors seem to account for this variation. First is a lack of clarity about the purpose of grading. Decisions about what evidence to use in determining students' grades are extremely difficult to make when the purpose of grading is unclear. Different sources of evidence vary in their appropriateness and validity depending on the identified purpose.

A second reason for the variation is the format used to report grades. Most high school reporting forms allow only a single grade to be assigned to students for each course or subject area. This compels teachers to distill all of these diverse sources of evidence into a single symbol. The result is a "hodgepodge grade" that includes elements of achievement, attitude, effort, and behavior. ${ }^{5}$ Even when teachers clarify the weighting strategies they use to combine these elements and employ computerized grading programs to ensure accuracy in their computations, the final grade remains a confusing amalgamation that is impossible to interpret and 
rarely presents a true picture of a student's proficiency. ${ }^{6}$

To make high school grades more meaningful, we need to address both of these factors. First, we must clarify our purpose in grading. Second, we must decide what evidence best serves that purpose and how best to communicate a summary of that evidence to parents and others.

\section{CLARIFYING PURPOSES AND CRITERIA}

When asked to identify the purpose of grading, most high school teachers indicate that grades should describe how well students have achieved the learning goals established for a course. In other words, grades should reflect students' performance based on specific learning criteria. Teachers and students alike prefer this approach because they consider it both fair and equitable. ${ }^{7}$ But, as described earlier, teachers use widely varying criteria to determine students' grades. In most cases, these can be grouped into three broad categories: product, process, and progress criteria.

Product criteria are favored by advocates of standardsbased or performance-based approaches to teaching and learning. These educators believe the primary purpose of grading is to communicate a summative evaluation of student achievement and performance. ${ }^{8}$ In other words, they seek to assess what students know and are able to do at a particular point in time. Teachers who use product criteria typically base grades exclusively on final examination scores, final reports or projects, overall assessments, and other culminating demonstrations of learning.

Process criteria are emphasized by educators who believe product criteria do not provide a complete picture of student learning. From their perspective, grades should reflect not only the final results but also how students got there. Teachers who consider effort or work habits when assigning grades are using process criteria, as are teachers who factor regular classroom quizzes, homework, punctuality of assignments, class participation, or attendance into grade calculations.

Progress criteria are used by educators who believe that the most important aspect of grading is how much students have gained from their learning experiences. Other names for progress criteria include "learning gain," "improvement scoring," "value-added learning," and "educational growth." Some educators draw distinctions between progress, which they measure backward from a final performance standard or goal, and growth, which is measured forward from the place a student begins on a learning continuum. ' However, when achievement is judged using well-defined learning standards that include graduated levels of performance, progress and growth criteria can be considered synonymous.

Teachers who use progress criteria typically look at how much improvement students have made over a specified period of time, rather than just where they are at any one point. As a result, the scoring criteria used in determining student grades may be highly individualized. Most of the current research evidence on the use of progress criteria in grading comes from studies of individualized instruction and special education programs. ${ }^{10}$

Because of concerns about student motivation, selfesteem, and the social consequences of grades, few teachers use only product criteria in determining grades. Instead, most routinely base their grading procedures on some combination of all three types of evidence. ${ }^{11}$ Many also vary their grading criteria from student to student, taking into account individual circumstances. ${ }^{12}$ Although teachers defend this practice on the basis of fairness, it seriously blurs the meaning of any grade. Interpreting grades thus becomes exceptionally challenging, not only for parents but also for administrators, community members, and even the students themselves. ${ }^{13} \mathrm{~A}$ grade of $\mathrm{A}$, for example, may mean that the student knew what was intended before instruction began (product), did not learn as well as expected but tried very hard (process), or simply made significant improvement (progress).

\section{CONFLICTING SOLUTIONS}

Recognizing these interpretation problems, most researchers and measurement specialists recommend the exclusive use of product criteria in determining students' grades. They point out that the more process and progress criteria come into play, the more subjective and biased grades become. ${ }^{14}$ How can a teacher know, for example, how difficult a task was for students or how hard they worked to complete it?

Many teachers point out, however, that if they use only product criteria in determining grades, some highability students will receive high grades with little effort, while the hard work of less-talented students will go unacknowledged. Consider, for example, two students enrolled in the same physical education class. The first is a well-coordinated athlete who can easily perform any task the teacher asks and so typically does not put forth serious effort. The second student is strug- 
gling with a weight problem but consistently tries hard, exerts extraordinary effort, and also displays exceptional sportsmanship and cooperation. Nevertheless, this student is unable to perform at the same level as the athlete. Few teachers would consider it fair to use only product criteria in determining the grades of these two students. ${ }^{15}$

Teachers also emphasize that, if only product criteria are considered, low-ability students and those who are disadvantaged - the students who must work hardest - have the least incentive to do so. These students find the relationship between high effort and low grades frustrating and often express their frustration with indifference, deception, or disruption. ${ }^{16}$

\section{A MEANINGFUL ALTERNATIVE}

An increasing number of teachers and schools have adopted a practical solution to the problems associated with incorporating these different learning criteria into student grades: they report separate grades or marks on each set of criteria. In other words, after establishing explicit indicators of product, process, and progress criteria, teachers assign a separate grade to each. In this way grades or marks for learning skills, effort, work habits, and learning progress are kept distinct from assessments of achievement and performance. ${ }^{17}$ The intent is to provide a better, more accurate, and much more comprehensive picture of what students accomplish in school.

While high school teachers in the United States are

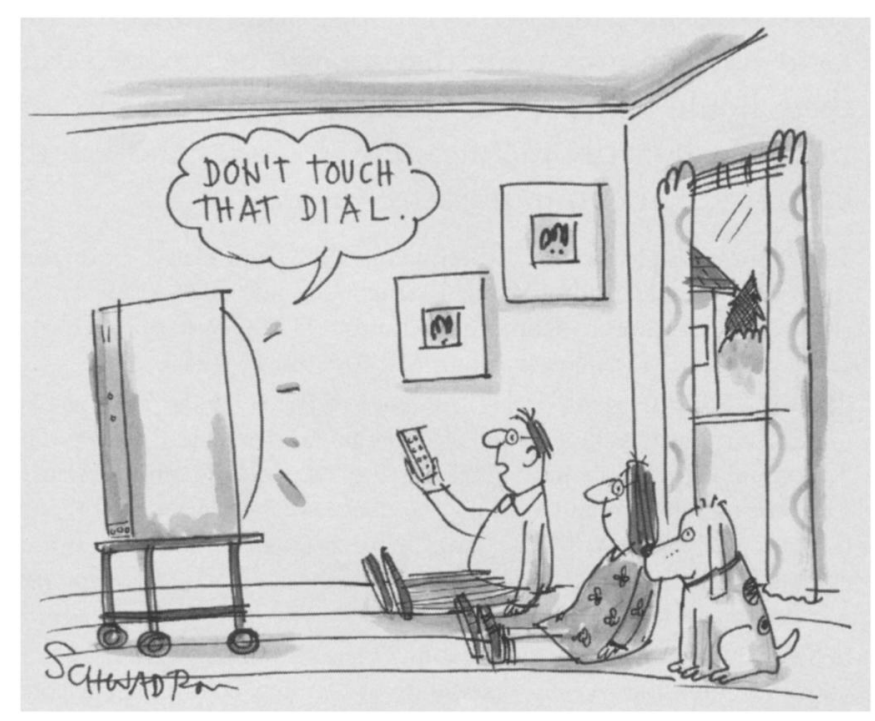

"What's a dial?" just beginning to catch on to the idea of separate grades for product, process, and progress criteria, many Canadian educators have used the practice for years. ${ }^{18}$ Each marking period teachers assign students an "achievement" grade based on the students' performance on projects, assessments, and other demonstrations of learning. Often expressed as a letter grade or percentage $(A=$ advanced, $B=$ proficient, $C=$ basic, $D=$ needs $\mathrm{im}$ provement, $\mathrm{F}=$ unsatisfactory), this "achievement" grade represents the teacher's judgment of the student's level of performance or accomplishment relative to explicit learning goals established for the course. Computations of grade-point averages and class ranks are based solely on these "achievement" or product grades.

In addition, teachers also assign separate grades or marks for homework, class participation, punctuality of assignment submissions, effort, learning progress, and the like. Because these factors usually relate to specific student behaviors, most teachers record numerical marks for each ( $4=$ consistently, $3=$ usually, 2 = sometimes, and $1=$ rarely). To clarify a mark's meaning, teachers identify specific behavioral indicators for these factors and for the levels of performance in each. For example, the indicators for a "homework" mark might include:

$4=$ All homework assignments completed and turned in on time.

3 = Only one or two missing or incomplete homework assignments.

2 = Three to five missing or incomplete homework assignments.

$1=$ Numerous missing or incomplete homework assignments.

Teachers sometimes question the need for this level of specificity. Upon reflection, however, most discover that by including homework assignments as part of an overall grade for students, they already face this challenge. When determining an overall grade, teachers must decide how much credit to give students for completing homework assignments or how much to take away for assignments that were turned in late or not at all. Similarly, when reporting a separate grade for homework, teachers must ensure that students understand the various performance levels so that they know what the mark signifies and what must be done to improve.

Often teachers presume that reporting multiple grades will increase their grading workload. But those who use the procedure claim that it actually makes grading easier and less work. Teachers gather the same evidence on student learning that they did when calculating an over- 
all grade but no longer worry about how to weight or combine that evidence. As a result, they avoid irresolvable arguments about the appropriateness or fairness of various weighting strategies.

Reporting separate grades for product, process, and progress criteria also makes grading more meaningful. If a parent questions the teacher about a product grade, for example, the teacher simply points to the various

\section{The key to success in reporting multiple grades rests on the clear specification of indicators related to product, process, \\ and progress criteria.}

process indicators and suggests, "Perhaps if your child completed homework assignments and participated more in class, the 'achievement' grade would be higher." Parents favor the practice because it provides a more comprehensive profile of their child's performance in school. Employers and college admission officers also like systems of separate grades because they offer more detailed information on students' accomplishments. With all grades reported on the transcript, a college admissions office can distinguish between the student who earned high achievement grades with relatively little effort and the one who earned equally high grades through diligence and hard work. The transcript thus becomes a more robust document, presenting a better and more discerning portrait of students' high school experiences. ${ }^{19}$

Schools would still have the information needed to compute grade-point averages and class rankings, if such computations are still deemed important. Now, however, those averages and rankings would be untainted by undefined aspects of process and progress. As such, they would represent a more valid and appropriate measure of achievement and performance. Furthermore, to the extent that classroom assessments and state accountability assessments are based on the same standards for learning, the relationship between product grades and accountability assessment results would likely be much higher.

The key to success in reporting multiple grades, however, rests on the clear specification of indicators related to product, process, and progress criteria. Teachers must be able to describe exactly how they plan to evaluate students' achievement, attitude, effort, behavior, and progress. Then they must clearly communicate these criteria to students, parents, and others.

\section{CONCLUSION}

The relationship between high school grades and students' performance on state accountability assessments will never be perfect. Grades are derived from courses that can vary significantly across schools and classrooms. In contrast, state accountability assessments typically are designed to measure proficiency based on a set of common standards for student learning. As such, the developers of these types of assessments purposefully avoid content that may be unique to particular learners or learning situations. Furthermore, course grades normally reflect a much broader range of knowledge and skills than can be measured by limited accountability assessments with restricted modes of student response. ${ }^{20}$ Nevertheless, concerns about honesty and fairness compel us to reduce the mismatch between these two important measures of student knowledge and skill.

Developing meaningful, reasonable, and equitable grading policies and practices will continue to challenge high school educators. The challenge remains all the more daunting, however, if we continue to use reporting forms that require teachers to combine so many diverse sources of evidence into a single grade. Distinguishing specific "product" criteria on which to base an "achievement" grade allows teachers to offer a better and more precise description of students' academic achievement and performance. To the extent that "process" criteria related to homework, class participation, attitude, effort, responsibility, behavior, and other nonacademic factors remain important, they too can be reported. But they should be reported separately. Adopting this approach will clarify the meaning of grades and greatly enhance their communicative value.

1. See, for example, Robert T. Brennan et al., "The Relative Equitability of High-Stakes Testing Versus Teacher-Assigned Grades: An Analysis of the Massachusetts Comprehensive Assessment System (MCAS)," Harvard Educational Review, Summer 2001, pp. 173-216.

2. Randy Elliot Bennett et al., "Influence of Behavior Perceptions and Gender on Teachers' Judgments of Students' Academic Skill," Journal of Educational Psychology, June 1993, pp. 347-56; John R. Hills, "Apathy Concerning Grading and Testing," Phi Delta Kappan, March 1991, pp. 540-45; and Clyde A. Wiles, "Investigating Gender Bias in the Evaluations of Middle School Teachers of Mathematics," School Science and Mathematics, October 1992, pp. 295-98.

3. Susan Austin and Richard McCann, "Here's Another Arbitrary Grade for Your Collection: A Statewide Study of Grading Policies," paper presented at the annual meeting of the American Educational Research Association, San Francisco, 1992; Roger A. Boothroyd and Robert F. McMorris, "What Do Teachers Know About Testing and How Did They 
Find Out?," paper presented at the annual meeting of the National Council on Measurement in Education, San Francisco, 1992; and Richard J. Stiggins, "Inside High School Grading Practices: Building a Research Agenda," Educational Measurement: Issues and Practice, Summer 1989, pp. 5-14.

4. Gregory J. Cizek, Shawn M. Fitzgerald, and Robert E. Rachor, "Teachers' Assessment Practices: Preparation, Isolation, and the Kitchen Sink," Educational Assessment, vol. 3, 1995/1996, pp. 159-79; and James H. McMillan, "Secondary Teachers' Classroom Assessment and Grading Practices," Educational Measurement: Issues and Practice, March 2001, pp. 20-32.

5. Susan M. Brookhart, "Grading Practices and Validity," Educational Measurement: Issues and Practice, March 1991, pp. 35-36; and Lawrence H. Cross and Robert B. Frary, "Hodgepodge Grading: Endorsed by Students and Teachers Alike," paper presented at the annual meeting of the National Council on Measurement in Education, New York, 1996.

6. See David T. Conley, "Who Is Proficient?: The Relationship Between Proficiency Scores and Grades," paper presented at the annual meeting of the American Educational Research Association, New Orleans, 2000; and Thomas R. Guskey, "Computerized Gradebooks and the Myth of Objectivity," Phi Delta Kappan, June 2002, pp. 775-80.

7. Marcia A. Kovas, "Make Your Grading Motivating: Keys to Performance Based Evaluation," Quill and Scroll, October/November 1993, pp. 10-11. 8. Stephen J. Friedman, "Grading Teachers' Grading Policies," NASSP Bulletin, April 1998, pp. 77-83; and Ken O'Connor, How to Grade for Learning: Linking Grades to Standards, 2nd ed. (Arlington Heights, Ill.: SkyLight, 2002).

9. See, for example, Grant Wiggins, "Honesty and Fairness: Toward Better Grading and Reporting," in Thomas R. Guskey, ed., Communicating Student Learning: 1996 Yearbook of the Association for Supervision and Curriculum Development (Alexandria, Va.: Association for Supervision and Curriculum Development, 1996), pp. 141-76.

10. Warren W. Esty and Anne R. Teppo, "Grade Assigniment Based on Progressive Improvement," Mathematics Teacher, November 1992, pp. 616-18; and Russell Gersten, Sharon Vaughn, and Susan U. Brengelman, "Grading and Academic Feedback for Special Education Students and Students with Learning Difficulties," in Guskey, Communicating Student Learning, pp. 47-57.

11. Susan M. Brookhart, "Teachers' Grading Practices: Meaning and Values," Journal of Educational Measurement, Summer 1993, pp. 123-142; Cross and Frary, op. cit.; Stephen J. Friedman and Merlin Manley, "Improving High School Grading Practices: Experts vs. Practitioners," NASSP Bulletin, vol. 76, 1992, pp. 100-104; Fe' Josefa G. Nava and Brenda H. Loyd, "An Investigation of Achievement and Nonachievement Criteria in Elementary and Secondary School Grading," paper presented at the annual meeting of the American Educational Research Association, San Francisco, 1992.

12. Stephen J. Friedman and Anthony J. Troug, "Evaluation of High School Teachers' Written Grading Policies," ERS Spectrum, Summer 1999, pp. 34-42; and Gary Natriello, Carolyn J. Riehl, and Aaron M. Pallas, Between the Rock of Standards and the Hard Place of Accommodation: Evaluation Practices of Teachers in High Schools Serving Disadvantaged Students (Baltimore: Center for Research on Effective Schooling for Disadvan-
Facilitator training for parent workshop leaders

Help parents prepare their children for success.

tified PESA Facilitator and lead parent workshops at your school!

demic achievement and school performance for the federal reform lecislation of

No Child Left Behind Act of 2001 (Title I, Sec. 1118. Parent Involvement).

PESA facilitator workshops are available in English, Spanish,

Chinese, Korean, and Armenian languages upon request.

nglish PESA Facilitator Trainings are scheduled for:

Jan. 25-26, 2007 - San Bernardino, CA

Feb. 6-7, 2007 - Miami, FL

Feb. 27-28, 2007 - Houston, TX

Mar. 13-14, 2007 - Anaheim, CA

May 10-11, 2007 - Ventura, CA

May 15-16, 2007 - Oklahoma City, OK

- The $\$ 300$ registration fee includes the 2-day training, PESA Facilitator Manual,

- Please call (800) 566-6651 for a Registration Form with locations.

SA Facilitator Training at your site and receive a discount on registration fees. request a registration form or additional information regarding the TESA or PESA programs, please call (800) 566-6651.

Look for the TESA training schedule on page 687 of this issue. E-mail: tesa_pesa@lacoe.edu Website: hittp://streamerlacoe.edu/PESA cosangetes coun

taged Students, Johns Hopkins University, 1994).

13. Stephen J. Friedman and David A. Frisbie, "The Influence of Report Cards on the Validity of Grades Reported to Parents," Educational and Psychological Measurement, February. 1995, pp. 5-26; Kristie K. Waltman and David A. Frisbie, "Parents' Understanding of Their Children's Report Card Grades," Applied Measurement in Education, vol. 7, 1994, pp. 223-40; and Warren W. Willingham, Judith M. Pollack, and Charles Lewis, "Grades and Test Scores: Accounting for Observed Differences," Journal of Educational Measurement, Spring 2002, pp. 1-37.

14. Allan C. Ornstein, "Grading Practices and Policies: An Overview and Some Suggestions," NASSP Bulletin, April 1994, pp. 55-64.

15. See Thomas R. Guskey and Jane M. Bailey, Developing Grading and Reporting Systems for Student Learning (Thousand Oaks, Calif.: Corwin Press, 2001).

16. Tommy Tomlinson, Hard Work and High Expectations: Motivating Students to Learn (Washington, D.C.: Office of Educational Research and Improvement, U.S. Department of Education, 1992).

17. Thomas R. Guskey, How's My Kid Doing? A Parent's Guide to Grades, Marks, and Report Cards (San Francisco: Jossey Bass, 2002); and Richard J. Stiggins, "Communicating with Report Cards," in idem, Student-Involved Assessment for Learning, 4th ed. (Upper Saddle River, N.J.: Pearson Education, 2005), pp. 275-319.

18. Jane Bailey and Jay McTighe, "Reporting Achievement at the Secondary Level: What and How," in Guskey, Communicating Student Learning, pp. 119-40.

19. Clifford Adelman, Answers in the Tool Box: Academic Intensity, Attendance Patterns, and Bachelor's Degree Attainment (Washington, D.C.: Office of Educational Research and Improvement, U.S. Department of Education, 1999).

20. Willingham, Pollack, and Lewis, op. cit. 